\title{
ИССЛЕДОВАНИЕ ИННОВАЦИОННО-ПРЕДПРИНИМАТЕЛЬСКОГО ОБРАЗОВАНИЯ И ПРАКТИКИ ИНОСТРАННЫХ СТУДЕНТОВ В КИТАЕ
}

\section{THE STUDY ON THE INNOVATION\&ENTREPRENEURSHIP EDUCATION AND PRACTICE FOR FOREIGN STUDENTS IN CHINA}

Yang Liyun

Summary: Innovation\&entrepreneurship education is becoming a hot spot of Chinese universities. With the enhancement of Chinese economy and the progress of strategic implementation of One Belt and One Road, China witnesses the increasing number of foreign students in China. This article analyzes the opportunities and practical demand for innovation\&entrepreneurship education and practice for international students in China, and introduces the current status of innovation\& entrepreneurship education and practice for international students in China in Chinese universities, and uses questionnaires to investigate the difficulties and demands of innovation\&entrepreneurship education and practice of foreign students in China. Finally, several suggestions are put forward in response to these difficulties and demands, in order to improve the innovation\&entrepreneurship education of Chinese universities for international students in China, and effectively improve the innovation \&entrepreneurship capabilities of international students in China.

Keywords: foreign students in China, innovation\&entrepreneurship education and practice, opportunities and needs, challenge\&solution.

\section{ПреАпосылки исслеАования}

$\mathrm{B}$ 2014 году премьер-министр Китая Ли Кэцян на Летнем форуме в Давосе официально выдвинул идею «массового предпринимательства и масштабных инноваций». Инновационное предпринимательство относится к предпринимательской деятельности, основанной на одной или нескольких инновациях в области технологических инноваций, инноваций в сфере услуг, инновационных бизнес-моделей, рынка инноваций, каналов инноваций и т.д. Инновация является основой и предпосылкой предпринимательства, а предпринимательство - воплощением и расширением инноваций. Фундаментальное различие между инновационным предпринимательством и традиционным предпринимательством заключается в том, присутствуют ли инновационные факторы в предпринимательской деятельности. Инновационно-предпринимательское образование стало одним из ключевых тенденций реформирования
Ян Лиюнь

Кандидат, Чжэизянский университет финансов и экономики, г. Ханчжоу, провинция Чжэизян, Китай 957033309@q9.com

Цзинь Дэфэн

Аспирант, Чжэизянский университет финансов и экономики, г. Ханчжоу, провинция Чжэизян, Китай

Аннотация: Инновационно-предпринимательское образование является горячим направлением китайских вузов. С ростом экономической мощи Китая и постоянным продвижением стратегии «0дин пояс - один путь» количество иностранных студентов в Китае год от года растет. В данной статье проанализированы благоприятные возможности и требования развития инновационно-предпринимательского образования и практики иностранных студентов в Китае, делается обзор текущего положения инновационно-предпринимательского образования и практики иностранных студентов в Китае, и с помощью вопросника исследованы трудности и требования иностранных студентов в Китае в области инновационно-предпринимательского образования и практики. И в конце концов выдвигаются некоторые предложения по совершенствованию инновационно-предпринимательского образования в китайских вузах для иностранных студентов и повышению инновационнопредпринимательских способностей иностранных студентов в Китае.

Ключевые слова: иностранные студенты, обучающиеся в Китае, инновационно-предпринимательское образование и практика, возможности и потребности, вызовы и ответы.

и развития высшего образования в Китае. Инновационно-предпринимательское образование в основном относится к образовательным концепциям и формам, направленным на развитие талантов с инновационнопредпринимательским мышлением, способностями и качеством посредством научного и систематического обучения в аудиториях и социальной практики. [1] Университеты играют важную роль в системе развития инновационно-предпринимательского образования. Проведение инновационно-предпринимательского образования в вузах является важной мерой для содействия интернационализации китайского высшего образования и важным способом развития инновационного духа и предпринимательских способностей у студентов.

Стабильная международная среда, политика Китая по постоянной поддержке открытости к внешнему миру, а также развитие экономики и высшего образования Китая обеспечивают вполне достаточные условия 
для обучения иностранных студентов. Согласно отчету «Глобальная гонка за таланты: сравнение государственных стратегий по привлечению иностранных студентов», Китай уже обогнал Францию и занял третье место в мире после Америки и Англии в качестве ведущей в мире страны-реципиента «циркуляции умов». Согласно опубликованным Министерством образования Китая в апреле 2019 года данным, в 2018 году в общей сложности 492185 иностранных студентов из 196 стран и регионов прошли обучение в 1004 высших учебных заведениях в 31 провинции, автономных регионах и городах прямого подчинения центральному правительству Китая, что на 3013 больше чем в 2017 году. Темп роста составил 0,62\% (все вышеперечисленные показатели не включают Гонконг, Макао и Тайвань). В топ-15 стран входят Южная Корея, Таиланд, Пакистан, Индия, США и Россия 1.

Образование иностранных студентов - важная часть высшего образования Китая. Это неизбежная тенденция интернационализации высшего образования Китая в отношении развития инновационно-предпринимательского образования для иностранных студентов.

\section{Анализ благоприятных возможностей развития инновашионно-преАпринимательского образования и практики $\Delta$ и иностранных студентов в Китае}

В 2013 году председатель Китая Си Цзиньпин в своей речи в Назарбаевском Университете в Казахстане выступил с инициативой совместного строительства «Экономического пояса Шелкового пути». Эта инициатива вызвала решительный отклик со стороны международного сообщества. Инициатива «Один пояс - один путь» открыла возможности для промышленных инноваций в Китае и создала более широкое пространство для развития внешней открытости высшего образования Китая.

Наряду с непрерывным прогрессом инициативы «Один пояс - один путь», Китай придает большое значение подготовке иностранных талантов, обучающихся в Китае. Таланты высшего уровня из числа иностранных студентов привлекаются такими методами как учреждение различных стипендий и усовершенствование политики по отношению иностранных студентов, обучающихся в Китае. Ожидается, что большое количество выдающихся иностранных талантов, обучающихся в Китае, станут важной силой в построении инновационного Китая в будущем.
Инициатива «Один пояс - один путь» реализовала дальнейшую интеграцию китайского и международного рынков. В этом контексте трансграничная электронная коммерция стала популярным направлением участия иностранных студентов в инновационно-предпринимательской практике. В качестве примера можно привести Международный инновационно-предпринимательский конкурс для студентов, впервые проведенный в китайской провинции Чжэцзян в 2018 году. В общей сложности было собрано 30 проектов по предпринимательству иностранных студентов в сфере трансграничной электронной коммерции.

На фоне новой эпохи Китай поднял инновационнопредпринимательское образование в вузах на беспрецедентный уровень. В рамках общей работы китайских вузов обучение иностранных студентов также является бенефициаром государственной политики. В «Докладе о развитии образования иностранных студентов в Китае» (2014 г.), составленном Аналитическим центром для Китая и глобализации (CCG) уже отмечалось, что если студенты с иностранным гражданством после завершения образования не могут напрямую трудоустроиться или начать бизнес в Китае, то иностранные таланты с инновационно-предпринимательским потенциалом будут в определенной степени утеряны. В докладе предлагается Китаю следовать тенденции международного потока талантов мира.

В апреле 2015 года Канцелярия ЦК КПК и Канцелярия Госсовета опубликовали «Некоторые соображения о проведении работы по повышению открытости образования для внешнего мира в новую эпоху²», в которых были приняты ключевые меры для проведения работы по повышению открытости образования для внешнего мира в новую эпоху, в том числе: ускорение обучения первоклассных и инновационных талантов, талантовносителей нечасто используемых языков, талантов в международной организационной работе, талантов для государственных и региональных исследований, а также прибывших в Китай неординарных талантов.

В 2017 году правительство Китая выпустило «Уведомление по вопросам, связанным с разрешением на трудоустройство в Китае для выпускников с иностранным гражданством, с отличием закончивших вузы ${ }^{3} »$, в котором указывалось, что «некоторая часть выпускников с иностранным гражданством, с отличием закончивших вузы, могут трудоустроиться в Китае без опыта работы».

\footnotetext{
1 Статистический отчет по иностранным студентам в Китае за 2018 год. Available at: http://www.moe.gov.cn/jyb_xwfb/gzdt_gzdt/ s5987/201904/t20190412_377692.html (accessed: 12.04.2019).

2 Некоторые соображения о проведении работы по повышению открытости образования для внешнего мира

в новую эпоху. Available at: http://www.gov.cn/home/2016-04/29/content_5069311.htm (accessed 29.04.2016).

3 Уведомление по вопросам, связанным с разрешением на трудоустройство в Китае для выпускников с иностранным гражданством, с отличием закончивших вузы. Available at: http://www.mohrss.gov.cn/xxgk2020/fdzdgknr/zcfg/gfxwj/jy/201701/t20170111_264214. html (accessed 06.01.2017).
} 
Обнародование соответствующих документов обеспечивает политическую поддержку развития инновационно-предпринимательского образования для иностранных студентов и их будущего предпринимательства в Китае. Это еще один важный шаг для Китая в активном привлечении международных талантов и создании международной конкурентоспособной системы талантов.

Инициатива «Один пояс - один путь» предоставляет китайским предприятиям беспрецедентные возможности для «выхода на мировой рынок» и в то же время выдвигает новые требования для китайских предприятий:

1. выдвигаются более высокие требования к инновационным способностям китайских предприятий. Инновации являются основой развития предприятий. Собственные научно-исследовательские институты и сотрудники предприятий являются важными ресурсами для улучшения возможностей предприятия.

2. Масштабы и объемы сотрудничества между Китаем и странами, расположенными вдоль «Одного пояса - одного пути», постоянно расширяются. На этом фоне контакты между Китаем и странами, расположенными вдоль «Одного пояса - одного пути», неизбежно требуют большого количества многопрофильных талантов, владеющих как языком, так и профессиональными знаниями для участия[2].

Насущные требования заставляют китайские предприятия еще больше осознавать необходимость обучения и набора иностранных студентов, обладающих инновационно-предпринимательскими способностями. Поэтому многие китайские предприятия рассматривают иностранных студентов как потенциальные инновационные таланты для своих компаний и активно стремятся сотрудничать с вузами, чтобы предоставить практические платформы для иностранных студентов путем создания вневузовских практическо-образовательных баз и иными способами, где иностранные студенты смогли бы практиковаться. Таким образом достигается «тройная победа» - для предприятий, университетов и иностранных студентов.

\section{Анализ насушных потребностей развития инновационно-преАпринимательского образования и практики м^я иностранных студентов в Китае}

Проводимое вузами развитие инновационно-предпринимательского образования для иностранных студентов - это не только предоставленная эпохой благоприятная возможность, но, вместе с этим, и насущная потребность.

В Китае вслед за непрерывным увеличением числа иностранных студентов идет постоянное улучшение качества их структурного состава и цензового уровня. Учебные специальности иностранных студентов в Китае также демонстрируют тенденцию к диверсификации. Согласно данным, опубликованным Министерством образования Китая в 2017 году, академическое распределение иностранных студентов в Китае стало еще более рациональным: число иностранных студентов, изучающих гуманитарные науки, по-прежнему занимает первое место, составляя 48,45 процента от общего числа. Число иностранных студентов, изучающих инженерное дело, менеджмент, естественные науки, искусство и сельское хозяйство, увеличилось более чем на $20 \%$ в год ${ }^{4}$. Хотя цели и потребности иностранных студентов в Китае неодинаковы, многие из них предпочитают учиться в Китае, потому что с оптимизмом смотрят на хорошие тенденции экономического развития Китая.

Многие иностранные студенты желают получить продвинутые знания в Китае и применить полученные в китайских вузах знания на практике ради карьерных достижений в будущем. Однако одни лишь языковые и культурные курсы вряд ли могут удовлетворить потребности иностранных студентов. Авторами статьи было проведено интервью с иностранными студентами в Чжэцзянском университете финансов и экономики, где многие из учащихся выразили намерение начать свой собственный бизнес после окончания учебы. Создание инновационно-предпринимательской среды для иностранных студентов и обучение их навыкам инноваций и предпринимательства являются важными шагами на пути к удовлетворению потребностей иностранных студентов в Китае.

Перед лицом глобального экономического кризиса, мировых экологических проблем и меняющейся международной ситуации предприниматели также должны иметь международное видение и способность решать глобальные проблемы [3]. Проведение инновационнопредпринимательского сотрудничества между китайскими и иностранными студентами способствует расширению международного видения студентов вузов и повышению их способности изучать передовые мировые научные дисциплины.

Китайские студенты могут в полной мере использовать ресурсы иностранных студентов из разных стран и проводить исследования в области инноваций и предпринимательства с иностранными студентами, изучаю-

4 С Министерство образования: в 2017 году в Китай приехали почти полмиллиона иностранных студентов на учебу, 88\% из них за свой счет. Available at:

https://baijiahao.baidu.com/s?id=1596331270402022805\&wfr=spider\&for=pc (accessed 30.03.2018). 
щими разные специальности в Китае. Исходя из неодинакового бэкграунда в плане происхождении и культурной среды, разница между китайскими и иностранными студентами в образе мышления, учебных навыках, структуре знаний и т.д. является достаточно большой. Во время занятий инновационно-предпринимательской деятельностью, китайские и иностранные студенты подчас разнятся в постановке акцентов и отправных точках. Подобная разница может не только расширять мировоззрение китайских и иностранных студентов, но, наряду с этим, также мотивировать и расширять кругозор инновационного мышления.

По мере дальнейшего развития экономической глобализации и социальной информатизации, интернационализация высшего образования стала основной реальностью в области высшего образования в современном мире, а также важной стратегической мерой для правительств разных стран по содействию модернизации образования. [4] Развитие инновационно-предпринимательского образования в вузах означает интеграцию «строительства инновационного Китая», «повышения степени интернационализации китайского высшего образования» и «подготовки инновационных талантов». В отличие от традиционной концепции образования путем вдалбливания и заучивания, инновационно-предпринимательское образование для иностранных студентов интегрирует межкультурные и трансграничные концепции в учебные курсы, поощряет студентов к активному развитию инновационного мышления и подчеркивает важность интеграции инновационных практик в образование, в целях повышения качества образования для иностранных студентов. Иностранные студенты, которые получают инновационно-предпринимательское образование в Китае, также могут экспортировать идеи китайского инновационно-предпринимательского образования в свои страны, тем самым повышая международное влияние китайского инновационно-предпринимательского образования. Проведение правительством и вузами Китая инновационно-предпринимательского образования для иностранных студентов и предоставление соответствующих услуг служат не только для удовлетворения потребностей современного развития Китая, но также является практическим способом повысить международную конкурентоспособность и дискурсивную силу китайского высшего образования.

Согласно данным, опубликованным Национальным научным фондом США (NSF), 70,7\% людей, родившихся в других странах и получивших докторскую степень в области науки или инженерии в Соединенных Штатах, обратились за временными визами для проживания в США после завершения учебы в 2012 году, таким образом став новой силой в технологическом и социально-экономическом развитии США. [5] На фоне экономической глобализации спрос Китая на международные таланты резко возрос. Иностранные студенты, обладающие профессиональными навыками и китайским языком, знающие Китай и его рынок изнутри, выбирают начинать бизнес в Китае и интегрироваться в команду экономического строительства Китая, что способствует продвижению интернационализации экономики Китая и повышению его общей экономической мощи. Развитие инновационно-предпринимательских способностей иностранных студентов - это резервирование международных талантов для Китая, что может еще больше активизировать китайский рынок. Кроме того, иностранные студенты обладают такими преимуществами как опыт обучения в Китае, опыт китайско-зарубежных контактов, а также преимущества обладания их родными языками. Благодаря этому они могут оказать мощную кадровую поддержку китайским предприятиям в деле «выхода на мировой рынок». Между иностранными студентами, обладающими инновационно-предпринимательскими способностями и китайскими предприятиями, мечтающими выйти на мировой рынок сформировалась двусторонняя связь.

\section{Анализ текушей ситуашии в сфере инновашионно-преАпринимательского образования и практики $\Delta$ ия иностранных сту ентов в Китае}

В настоящее время, наряду с созданием в Китае инновационно-предпринимательских институтов и открытием инновационно-предпринимательских курсов, инновационно-предпринимательское образование для китайских студентов добилось большого прогресса. Однако ощущается дефицит инновационно-предпринимательского образования для иностранных студентов. В настоящее время инновационно-предпринимательские институты в большинстве вузов Китая не полностью открыты для иностранных студентов, и лишь в отдельных вузах инновационно-предпринимательские институты принимают иностранных студентов. Инновационнопредпринимательский институт Вэньчжоуского университета - первое учебное заведение в Китае, которое принимает и подготавливает иностранных студентов со степенью магистра в области предпринимательского образования.

Во-вторых, инновационно-предпринимательские курсы в вузах носят спорадический и отрывочный характер. инновационно-предпринимательские курсы в вузах не могут охватывать всех иностранных студентов, и только иностранные студенты некоторых специальностей могут иметь доступ к некоторым инновационно-предпринимательским курсам. Шохрух Нормирзаев, студент из Узбекистана, обучающийся на факультете финансов Чжэцзянского университета финансов и экономики в Китае, принял участие в «Первом инновационно-предпринимательском конкурсе для иностранных 
студентов, обучающихся в 100 вузах Китая» и занял там третье место. Шохрух сказал, что его вуз открыл некоторые курсы по бизнесу и предпринимательству. Однако Алина, студентка из России, обучающаяся на факультете английского языка, отметила, что у них совершенно нет инновационно-предпринимательских курсов.

Хотя китайские вузы, в настоящее время предлагающие инновационно-предпринимательские курсы для иностранных студентов, находятся на стадии исследования, однако количество и качество инновационно-предпринимательских конкурсов для иностранных студентов постоянно улучшаются при участии и под руководством китайских преподавателей на протяжении всего этого процесса. Иностранные студенты могут честно и открыто принять участие в конкурсе, чтобы повысить свои инновационные и предпринимательские способности. На сегодняшний день инновационно-предпринимательские конкурсы для иностранных студентов можно разделить на следующие основные категории:

Первая категория: совместно проводимые конкурсы

В большинстве случаев инновационно-предпринимательские конкурсы, ориентированные на иностранных студентов, проводятся совместно многими организациями, включая правительственные органы, федерации, вузы, предприятия и т.д. Например, Китайский международный инновационно-предпринимательский конкурс для студентов «Интернет Плюс» проводится совместно Министерством образования Китая, правительственными органами и вузами. Данный конкурс дал старт международным соревнованиям в 2019 году. Конкурс ориентирован на иностранных студентов, обучающихся в Китае и студентов, получающих образование за рубежом. Также допускается создавать интернациональные команды, при этом поощряется командное сотрудничество между китайскими и иностранными студентами. Другие совместно проводимые конкурсы включают в себя Инновационно-предпринимательский Конкурс АСЕАН для иностранных студентов (организатор: Организационный комитет образовательного обмена Китай-АСЕАН и Гуйчжоуский университ) и т. п. конкурсы.

Вторая категория: конкурсы, проводимые правительством

В целях углубленной реализации государственной стратегии развития по инновационному пути и удовлетворения потребностей иностранных студентов в инновациях и предпринимательстве, центральные и местные органы власти Китая активно проводят различные конкурсы для развития инновационно-предпринимательских способностей иностранных студентов. В 2019 году Управление кадров и социального обеспечения города Нанкин в китайской провинции Цзянсу провело пер- вый «Инновационно-предпринимательский конкурс для иностранных студентов, обучающихся в 100 вузах Китая», который привлек к себе 153 иностранных студента из китайских вузов.

Кроме того, проводятся конкурсы под эгидой федерации (Инновационно-предпринимательский конкурс в области трансграничной электронной коммерции для иностранных студентов из стран, находящихся по маршруту «Один пояс - один путь»), и конкурсы, проводимые силами предприятий и вузов, и все они ориентированы на иностранных студентов.

Осознавая важность развития у иностранных студентов инновационно-предпринимательских способностей, многие местные органы власти и вузы в Китае активно создают платформы инновационно-предпринимательской практики для иностранных студентов, в том числе следующие:

Проведение серии инновационно-предпринимательских мероприятий для иностранных студентов в целях разъяснения текущей политики и положений Китая в отношении предпринимательства в Китае, а также исследования бизнес-среды и бизнес-возможностей для инноваций и предпринимательства в Китае с практической точки зрения, чтобы обеспечить иностранным студентам руководство и помощь в инновациях и предпринимательстве в Китае.

Создание базы инновационно-предпринимательской практики для иностранных студентов. В целях послужить государственной инициативе «Один пояс один путь» и простимулировать местное экономическое строительство, китайские органы власти и университеты усердно работали над созданием инновационно-предпринимательской атмосферы и созданием практической платформы для иностранных студентов. В Китае Чунцинский университет (2018 г.), город Сиань (2019 г.), Университет внешней торговли Китая (2017 г.), а также другие регионы и вузы создают инновационно-предпринимательской базы для иностранных студентов, позволяющие им пользоваться высококачественными социальными ресурсами.

Активная организация посещения предприятий иностранными студентами. Посещая предприятия, иностранные студенты в полной мере могут лучше понять социальное, культурное и экономическое развитие Китая. Иностранные студенты, которые намерены начать бизнес в Китае, могут получить рациональные знания и опытную поддержку со стороны предприятий. Приведем в качестве примера Чжэцзянский университет финансов и экономики, данный вуз ежегодно организует иностранных студентов посещать компании Алибаба, Hikvision и другие известные китайские предприятия. 
В целях наилучшего понимания потребности иностранных студентов в инновациях и предпринимательстве, авторы статьи предприняли анкетный опрос среди 328 иностранных студентов, учащихся в Чжэцзянском университете финансов и экономики в Китае, и в общей сложности было собрано 209 экземпляров анкет. Большинство дисциплин и специальностей в университетах финансов и экономики относятся к современной сфере услуг. Особенность подготовки талантов в университетах финансов и экономики - это продвижение инноваций и предпринимательства с помощью различных специальностей, таких как бухгалтерский учет, финансы и кредит, налогообложение, маркетинг, информация, право и т.д. [6] Поэтому университеты финансов и экономики обладают уникальными преимуществами в развитии инновационно-предпринимательского образования и практики для иностранных студентов. Иностранные студенты, обучающиеся в университетах финансов и экономики, с большим энтузиазмом относятся к инновациям и предпринимательству.

Согласно анализу опроса, 88,89\% иностранных студентов проявили интерес к участию в инновационнопредпринимательском конкурсе, в то время как лишь около $15 \%$ иностранных студентов имеют опыт участия в таких конкурсах. Свыше 75\% иностранных студентов планируют начать свой собственный бизнес после окончания учебы. Оценка иностранных студентов к инновационно-предпринимательской среде в Китае отображается следующим образом: Рис. 1.

Согласно результатам опроса, требования иностранных студентов в Китае к инновациям и предпринимательству конкретно отображаются следующим образом: Рис. 2.
Анализируя опрос, стоит отметить, что иностранные студенты также сталкиваются с большими трудностями и проблемами при участии в инновационно-предпринимательских конкурсах и практиках, в том числе с такими: Рис. 3.

Как видно на приведенной выше иллюстрации, для иностранных студентов, недостаток опыта в области инноваций и предпринимательства является самой большой проблемой, сразу за которой следует языковой барьер. В будущем вузы должны уделять больше внимания проведению деятельности по обмену инновационнопредпринимательским опытом для иностранных студентов и усилению повышения их языкового уровня.

\section{Встречные меры и рекомендашии по развитию инновационно-преАпринимательского образования и практики Аля иностранных студентов в Китае}

В связи с особым статусом иностранных студентов, в отношении развития инновационно-предпринимательского образования необходимо внести некоторые коррективы на основе рекомендаций по инновационно-предпринимательскому образованию для китайских студентов.

Ввиду недостатка глубокого понимания предпринимательской среды и политики Китая у иностранных студентов, особенно важными представляются высшее образование и профессиональное руководство преподавателей. Согласно анкетированию иностранных студентов, 52,53\% из них полагают, что открытие инновационно-предпринимательского курса имеет чрезвычайную важность.

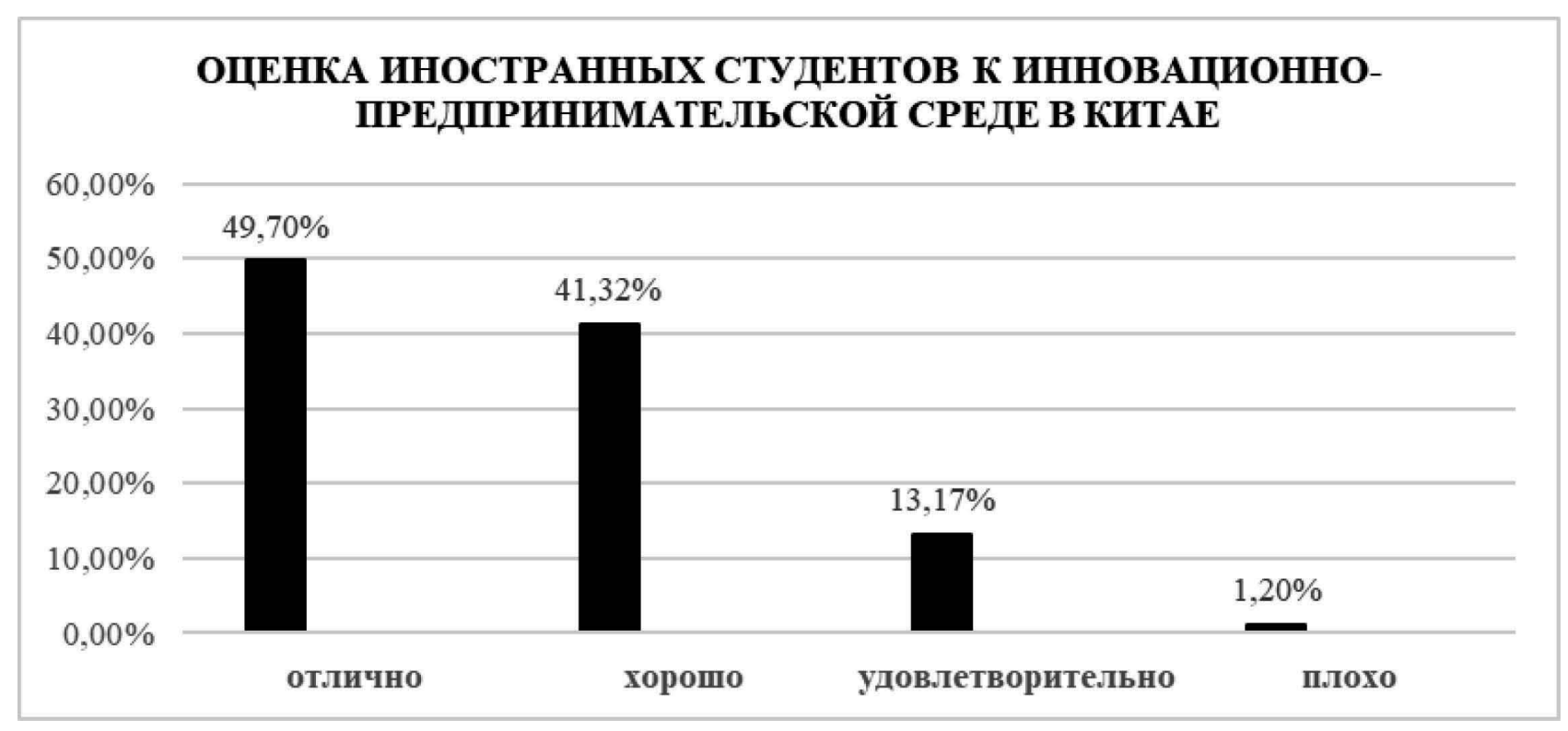

Рис. 1. 


\section{ТРЕБОВАНИЯ ИНОСТРАННЫХ СТУДЕНТОВ К ИННОВАЦИЯМ И ПРЕДПРИНИМАТЕЛЬСТВУ}

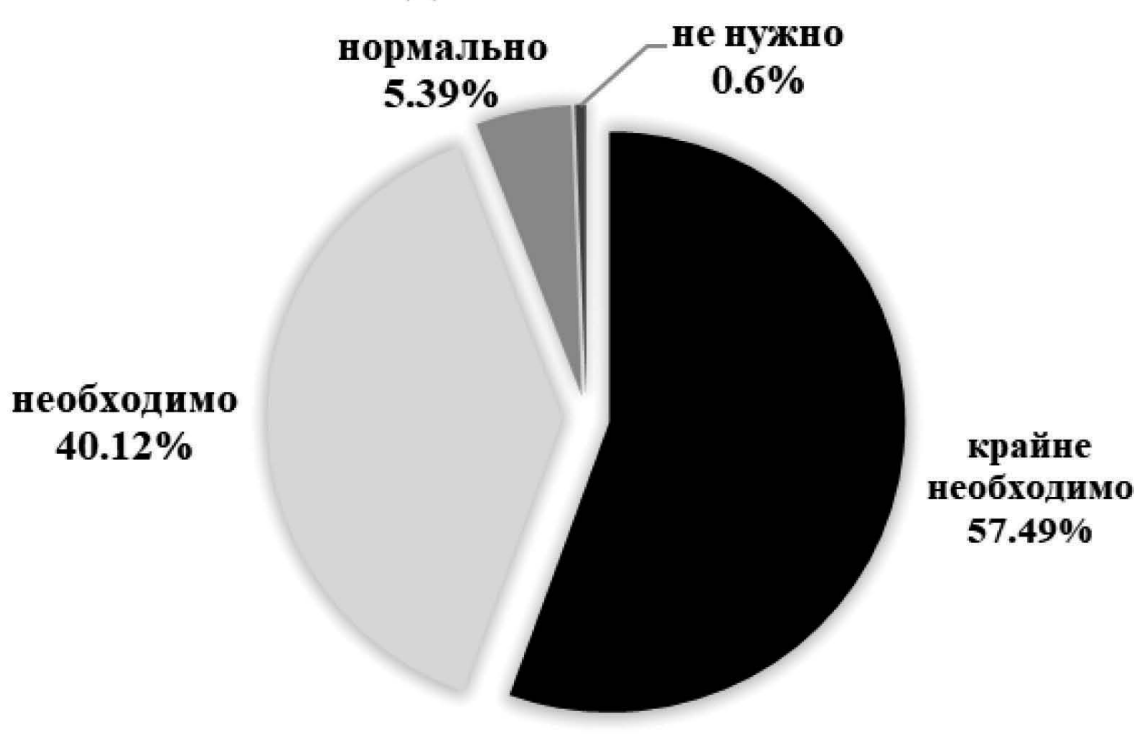

Рис. 2.

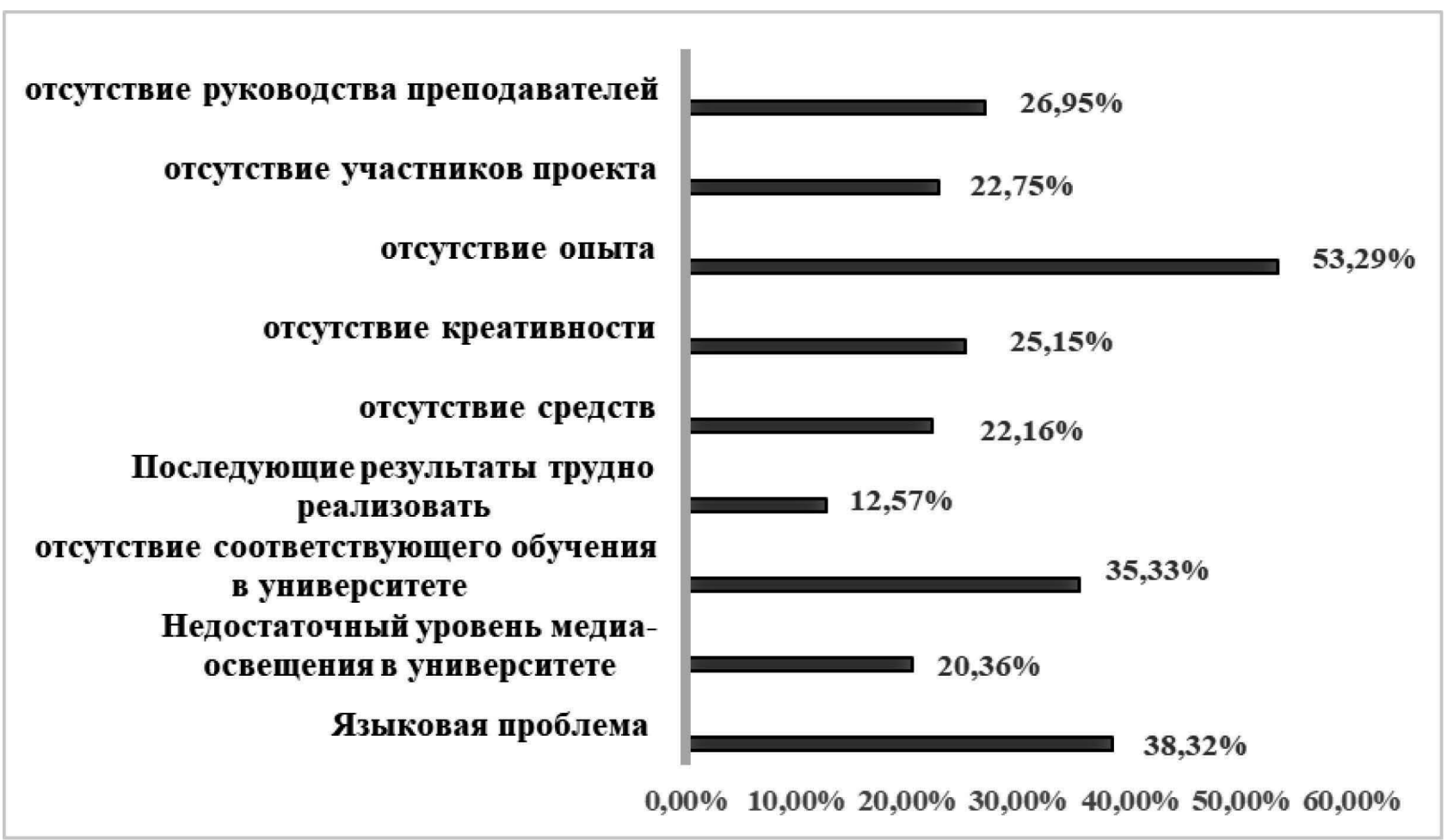

Рис. 3.

Для развития инновационно-предпринимательского образования для иностранных студентов, необходимо сперва начать с учебного курса:

1. Вузы должны открывать все инновационно-предпринимательские курсы для иностранных студентов.
2. Учебная программа должна быть диверсифицирована. В соответствии со специальностями и конкретными потребностями иностранных студентов, инновационно-предпринимательские курсы должны быть определены как обязательные кур- 
сы, факультативные курсы, краткосрочные предпринимательские курсы и модели др.

3. Преподаватель - ключ к достижению высокого уровня обучения, основа и движущая сила для профессионального непрерывного развития. [7] Вузы должны уделять внимание подготовке педагогических кадров, способных взять на себя инновационно-предпринимательское образование для иностранных студентов. Языковой барьер является важным фактором, ограничивающим инновации и предпринимательство иностранных студентов. Поэтому преподаватели в вузах могут вести занятия как на китайском, так и на английском языках.

4. Разработка учебных материалов на английском и китайском языках. В настоящее время учебники по инновациям и предпринимательству в китайских вузах в основном представлены на китайском языке, что не может удовлетворять языковые потребности иностранных студентов. Следовательно, разработка учебных материалов на английском и китайском языках будет способствовать лучшему пониманию преподаваемого материала иностранными студентами, и также поможет создать новую модель системы образования с китайскими особенностями для иностранных студентов.

Согласно анкетированию, до 86 процентов иностранных студентов считают руководство научного преподавателя очень важным. Руководящие преподаватели, обладающие практическим опытом и способностью преодолевать языковые барьеры, могут давать профессиональные и эффективные указания для иностранных студентов. Модель «двойного научного руководителя»: руководитель в вузе + руководитель на предприятии, может удовлетворить реальный спрос студентов в области инноваций и предрпинимательства. Преподаватели вузов сосредоточили внимание на теории, а сотрудники компании - на практике. Использование модели «двойного научного руководителя» укрепит инновационнопредпринимательское образование и практику иностранных студентов в Китае.

Чистое теоретическое образование не в состоянии реализовать истинное содержание инноваций и предпринимательства, и конечной целью подготовки инновационно-предпринимательских способностей у студентов вузов являются применение и практика. Согласно анализу результатов анкетирования, 59,6\% иностранных студентов считают, что внутривузовские курсы и практика имеют одинаково важное значение. 83,84\% иностранных студентов полагают, что практика на предприятиях - это оптимальный путь для повышения уровня инновационно-предпринимательских способностей иностранных студентов. Хотя платформа практики в сфе- ре инноваций и предпринимательства для иностранных студентов уже достигла своего первоначального развития, ее возможности по-прежнему ограничены. По этой причие, вузы должны усилить работу по созданию практической платформы для иностранных студентов, чтобы они смогли понять рыночный спрос и социальную реальность в Китае, а также целевым образом улучшать свои практические инновационно-предпринимательские способности.

Кроме того, основная проблема, с которой сталкивается инновационно-предпринимательская практика для иностранных студентов в китайсуих вузах, заключается в том, что проекты, по которым иностранные студенты участвуют в инновационно-предпринимательских конкурсах, не могут быть реализованы в будущем и остаются только на теоретическом уровне. Для того, чтобы своевременно трансформировать инновационно-предпринимательские знания и достижения в рыночно ориентированные товары, получая при этом прибыль, требуется задействовать силы предприятий. С этой целью государство должно всемерно выступать с инициативой, суть которой заключается в том, что предприятия взяли бы на себя «инкубационную» роль в работе по молодежным инновациям, выдвигать платформу для финансовой поддержки, а также спонсировать китайских и иностранных студентов в деле введения инновационно-предпринимательской практики. [8]

В будущем необходимо укреплять взаимную связь между правительством, вузами и предприятиями, а также создавать механизмы сотрудничества между промышленностью, образованием и исследованиями, такие как совершенствующиеся инкубаторы инноваций и предпринимательства. Это необходимо для содействия осуществлению инновационно-предпринимательских проектов для иностранных студентов. После этого необходимо реализовать органическое сочетание образовательной цепочки, цепочки талантов, производственной цепочки и инновационной цепочки.

Несмотря на то, что иностранные студенты в китайсуих вузах с энтузиазмом относятся к инновациям и предпринимательству, однако согласно анкетному опросу известно, что 38,38\% иностранных студентов так и не слышали об инновационно-предпринимательской конкуренции. В результате анализа инновационнопредпринимательских конкурсов для иностранных студентов в Китае за последние годы, можно увидеть, что большинство из награжденных иностранных студентов прибыли из общепрофильных университетов, финансово-экономических университетов, профессионально-технических институтов и других вузов с достаточно сильной степенью специализированности. При этом число награжденных иностранных студентов из педагогических университетов, медиа-университетов и других 
гуманитарных университетов сравнительно невелико. В будущем правительство и вузы должны распространять среди иностранных студентов информацию об инновациях и предпринимательстве, включая различные мероприятия, такие как встречи по обмену опытом в области инноваций и предпринимательства, лекции по предпринимательской политике и поездки руководителей по предпринимательству в университетские кампусы, для того чтобы еще больше укрепить атмосферу инноваций и предпринимательства в вузах.

Помимо того, преподаватели могут рассказывать иностранным студентам истории о предпринимательстве бизнесменов в провинции Чжэцзян и Шанхая, а также о других китайских традиционных путях ведения бизнеса; давать иностранным студентам обширную информацию к деловым биографиям Ма Юня, Жэнь Чжэнфэя и других известных современных китайских предпринимателей, чтобы иностранные студенты смогли по-настоящему прочувствовать предпринимательские истории и новаторский дух китайских предпринимателей.

\section{Зак^ючение}

Совершенствование модели инновационно-предпринимательского образования для иностранных студентов является важной практикой в подготовке международных талантов инновационного типа в китайских вузах, а также и эффективным подходом к стимуляции интернационализации китайского высшего образования. Поэтому правительство и вузы Китая придают большое значение инновационно-предпринимательскому образованию и практике иностранных студентов. Для китайских вузов подготовка и повышение инновационно-предпринимательских способностей иностранных студентов являются совершенно новым делом, и данный процесс протекает далеко не так гладко как хотелось бы. В настоящее время обучение и практика иностранных студентов в области инноваций и предпринимательства сталкиваются со множеством препятствий. Для того чтобы преодолеть в будущем эти препятствия и продвигать инновационно-предпринимательские способности у иностранных студентов, необходимо активное взаимодействие между государством, обществом, вузами и широкими массами иностранных студентов.

\section{ЛИТЕРАТУРА}

1. Ли Минхун, Сюй Сыхуа. Изучение и исследование инноваций и предпринимательства у иностранных студентов на фоне «Одного пояса и одного пути» [J]. Интеллект Инновационно-предпринимательское образование. 2020. №3. р.129.

2. Сунь Фан. Подготовка талантов неуниверсальных языков на службе инициативы «Один пояс - Один путь» [J]. Преподавание русского языка в Китае. 2020. №4. pp.68-75.

3. Сюй Сяочжоу, Ни Хао, У Цзинчао. Тенденции международного развития предпринимательского образования и трансформация концепций предпринимательского образования в Китае [J]. Исследования высшего образования в Китае. 2017. №4. pp.92-97. DOI: 10.16298 / j.cnki.1004-3667.2017.04.14.

4. Гао Чжэнжун. Некоторые размышления по поводу всестороннего продвижения интернационализации высшего образования [J]. Высшее образование Китая. 2016. №3. pр.18-20.

5. Ван Цзюнь. Базовое позиционирование и встречные меры в области образования для иностранных студентов в Китае [J]. Исследования высшего образования в Китае. 2014. №8. pp.88-92. D0I: 10.16298 / j.cnki.1004-3667.2014.08.017

6. Ч Чжун Сяоминь. Как следует развивать и усилять инновационно-предпринимательское образование в университетах [N]. Гуанмин Жибао. 2016. №6. pр.1-4.

7. Дин Чао. Несколько мыслей о реформе и инновациях в механизме подготовки иноязычных талантов [J]. Преподавание иностранных языков в Китае. 2018. №1. pp.3-9.

8. Ли Линьша, Мэн Линчунь. Проявление «кремневого» эффекта у иностранных студентов вузов в области молодежных инноваций и предпринимательства [J]. Синьцзянский форум социальных наук. 2016. №3. pp.70-73. 